\title{
Effect of Verticillium dahliae Soil Inoculum Levels on Spinach Seed Infection
}

Rumakanta Sapkota, Merete Halkjær Olesen, Lise Christina Deleuran, Birte Boelt, and Mogens Nicolaisen, Department of Agroecology, Faculty of Science and Technology, Aarhus University, Forsøgsvej 1, 4200 Slagelse, Denmark

\begin{abstract}
Sapkota, R., Olesen, M. H., Deleuran, L. C., Boelt, B., and Nicolaisen, M. 2016. Effect of Verticillium dahliae soil inoculum levels on spinach seed infection. Plant Dis. 100:1564-1570.

Verticillium dahliae is a soilborne pathogen and a threat to spinach seed production. The aim of this study was to understand the relation between V. dahliae soil inoculum and infection in harvested seed. Quantitative polymerase chain reaction was used for quantification of the pathogen. Semifield experiments in which spinach was grown in soils with different inoculum levels enabled us to determine a threshold level for $V$. dahliae DNA of $0.003 \mathrm{ng} / \mathrm{g}$ of soil for seed infection to occur. Soils from production fields were sampled in 2013 and 2014 during and before planting, as

well as the harvested seed. Seed from plants grown in infested soils were infected with $V$. dahliae in samples from both the semifield and openfield experiments. Lower levels of pathogen were found in seed from spinach grown in soils with a scattered distribution of $V$. dahliae (one or two positive of three soil subsamples) than in soils with a uniform distribution of the pathogen (three of three positive soil subsamples). Our results showed that infection of $V$. dahliae in harvested seed strongly depended on the presence of pathogen inoculum in the soil.
\end{abstract}

Verticillium dahliae Kleb. is an economically important soilborne plant pathogen infecting several species of vegetable crops, including spinach, lettuce, pepper, tomato, and eggplant (Klosterman et al. 2009). V. dahliae was reported in commercial spinach (Spinacia oleracea L.) seed lots in 2005, and the pathogen has been of concern for spinach seed production since then (du Toit et al. 2005). Denmark is one of the major suppliers of spinach seed worldwide (Deleuran 2011). Fresh-market or processing spinach does not display symptoms of Verticillium wilt because symptoms generally appear later in the season, after initiation of bolting (du Toit et al. 2005). Hence, diagnosis of the pathogen based on the symptoms alone is challenging.

$V$. dahliae can be transmitted to new spinach plants through seed or through the soil (du Toit et al. 2005; Inderbitzin and Subbarao 2014) but seedborne transmission has been the focus in most studies (du Toit and Hernandez-Perez 2005; du Toit et al. 2005). Once the soil is infested with $V$. dahliae, disease management is difficult because of the extensive host range of $V$. dahliae, absence of effective soil treatments, and survival of the pathogen in the soil for several years (Daayf 2014; Inderbitzin and Subbarao 2014; Luo et al. 2014; Wilhelm 1955). Therefore, it is vital to quantify the pathogen in the soil as a management tool in spinach seed production.

Several methods exist for detection and quantification of $V$. dahliae such as dilution plating (Kabir et al. 2004) and quantitative polymerase chain reaction (qPCR) assays for $V$. dahliae associated with spinach seed (Duressa et al. 2012) or soil (Bilodeau et al. 2012). $V$. dahliae produces dark melanized resting structures known as microsclerotia, which are important for overwintering of the pathogen in soil, seed, or plant debris. Dilution plating provides a measure of viable inoculum in the sample because only germinating microsclerotia will be counted on the agar plates (Harris and Yang 1996). However, this method is time consuming and needs expertise to identify microsclerotia and colonies. qPCR is a quick, highly sensitive, and reliable method for detection and quantification of $V$. dahliae. However, it fails to discriminate between dead and viable inoculum and, thus, could be misleading if the sample has been treated to reduce inoculum levels (Sanzani et al. 2014).

Corresponding author: M. Nicolaisen; E-mail: mn@agro.au.dk

Accepted for publication 24 March 2016.

http://dx.doi.org/10.1094/PDIS-01-16-0058-RE

(C) 2016 The American Phytopathological Society
Highly sensitive quantification of $V$. dahliae using qPCR opens the possibility to quantify the pathogen in nonfumigated commercial fields before planting. Early detection of the pathogen could be valuable in crop management to prevent disease spread (Sanzani et al. 2014; Schena et al. 2004) and buildup of pathogen inoculum. Quantification of microsclerotia in soil and its correlation to disease development have been implemented in potato, tomato, and strawberry (Fradin and Thomma 2006; Harris and Yang 1996; Nicot and Rouse 1987). However, knowledge about inoculum levels in cultivated soil and possible implications for spinach seed quality is limited.

The main objective of this study was to determine the effect of soil infestation of $V$. dahliae on spinach seed production. In order to do this, we (i) implemented a qPCR assay (Bilodeau et al. 2012) for quantification of the pathogen in soil and in spinach seed, (ii) quantified pathogen DNA in soil and harvested seed from pots with controlled levels of $V$. dahliae inoculum, and finally (iii) studied infestation levels of soil and harvested seed in commercial seed production plots.

\section{Materials and Methods}

Seed material. Commercially grown spinach hybrids were used in this study. All seed for crop establishment and harvested seed were provided by the Danish seed industry. Seed samples were taken in accordance with ISTA sampling protocols (ISTA 2011). A sample of $250 \mathrm{~g}$ was taken by thoroughly mixing and pouring the sample evenly into a tray. Small portions of seed were then taken with a spoon from not less than five random places in the sample. These subsamples were used for the seed health tests (freeze-blotter tests and qPCR).

Semifield experiment. The effect of soil inoculum levels on transmission of $V$. dahliae in spinach seed was evaluated in pot experiments using dilutions of infested soil. Pot experiments were conducted as an outdoor pot experiment at our semifield facilities at Aarhus University in the spinach-growing seasons of 2013 and 2014. The semifield facilities consisted of open screenhouses with a plastic roof and drip irrigation. A heavily infested soil with natural populations of $V$. dahliae was used. The heavy infestation of the soil was confirmed by observing symptoms of wilting at the late maturity stage in spinach seed plants (Olesen et al. 2014), by dilution plating, and by using the qPCR assay used throughout this study. Noninfested soil was collected from a field with no history of $V$. dahliae host plants; in addition, the soil had been tested negative for $V$. dahliae by dilution plating and the qPCR assay. Pots (10 liters) were three-quarters filled with the noninfested soil and the upper one-quarter layer was filled with dilutions of the $V$. dahliae infested soil in the noninfested soil. The eight soil dilutions of the infested 
and noninfested soils were $1: 0 ; 1: 0.75 ; 1: 1.5 ; 1: 3 ; 1: 6 ; 1: 12 ; 1: 24$, and $0: 1$ in four replicates, resulting in a total of 32 pots. Pots were arranged in a fully randomized design. In the beginning of May, 20 spinach seeds were sown in each pot and thinning was done after 2 weeks to grow six plants per pot. At maturity (at least $75 \%$ of the seed had matured as indicated by white and firm perisperm), seed were harvested. During growth, each pot was irrigated three times a day with an automatic drip irrigation system. The growing season was from the beginning of May to early August.

Soil sampling from commercial fields. In order to evaluate soil inoculum levels and the influence on seed infection levels, commercial spinach fields over a wide geographic area in Denmark were sampled in 2013 and 2014. Distribution of soil sampling plots in the year 2013 and 2014 is shown in Figure 1. The soil sampling strategy was different in the 2 years. In 2013, soil samples were collected from eight commercial spinach seed production fields where visual symptoms of $V$. dahliae wilt were observed. Soil samples were collected in July and August. A standard soil auger ( $2.5 \mathrm{~cm}$ in diameter) was used to sample soil from the upper $20-\mathrm{cm}$ soil layer. Five soil samples were taken at 5-m intervals along a diagonal line starting from where symptoms were detected (Fig. 2A). Two soil cores were collected at each site and pooled into one soil sample. In 2014, the number of fields was 25 and, in total, eight subsamples were taken per field in three categories. The selection of fields was based on the cropping history going 6 years back. Fields with three different crop rotation histories were selected: (i) fields in which spinach had been grown at least once during the last 6 years ( 7 fields); (ii)

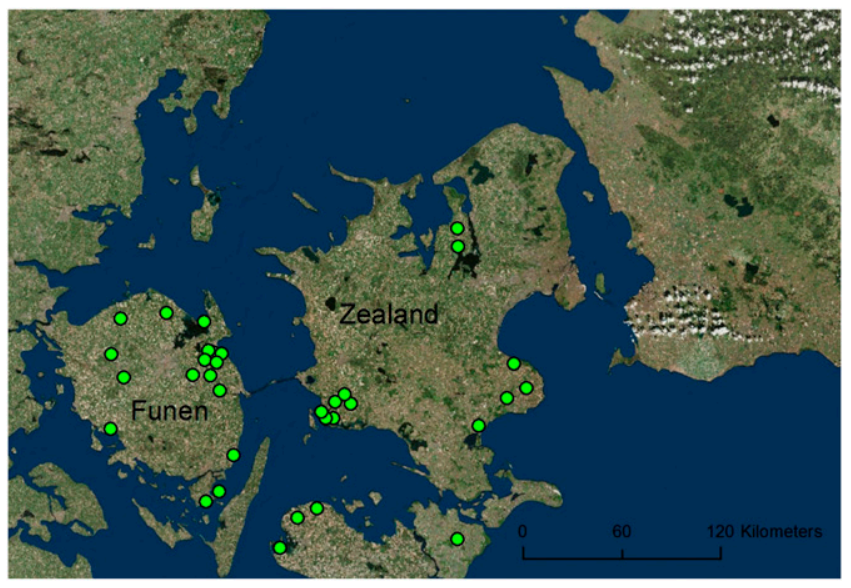

Fig. 1. Map showing distribution of fields sampled within Denmark in the year 2013 and 2014. fields in which other $V$. dahliae host species such as potato, pea, or beet had been grown at least once ( 8 fields); and (iii) fields in which no reported $V$. dahliae host species had been grown (mainly cereals and grasses for seed production) (10 fields). Soil samples were taken from the fields in March or April, before the spinach crop was established. A representative area of 1 ha was selected within each field and eight subsamples were collected at 20-m intervals in the pattern shown in Figure 2B. Each subsample consisted of two adjacent cores that were pooled. The soil sampling strategy was adopted from earlier studies of $V$. dahliae in potato and cauliflower fields (Smith and Rowe 1984; Xiao et al. 1997).

Soil sample preparation. Soil samples from 2013 were freeze dried for $48 \mathrm{~h}$. In 2014, soil samples were air dried at $40^{\circ} \mathrm{C}$ for $72 \mathrm{~h}$. Subsequently, the soil samples were sifted through a sieve (2-mm pore size) to remove stones and other larger particles. A subsample of $100 \mathrm{~g}$ from the mixed soil was used for subsequent processing. Before DNA extraction, the samples were ground in a bead mill (Retsch MM301 Mixer Mill) for $10 \mathrm{~min}$ and thereafter stored at $-20^{\circ} \mathrm{C}$ until analysis. In 2013, three of five sampling points (numbers 1,3,5) from each field were analyzed separately (Fig. 2, 2013) Similarly, in soil samples from 2014, three of eight samples (numbers 1, 3, 5) from each field were analyzed separately (Fig. 2, 2014). Moreover, a combined sample of eight subsamples was prepared by mixing thoroughly, and $250 \mathrm{mg}$ of soil was used for DNA extraction. In 2013, a representative subsample of $2.5 \mathrm{~g}$ from each of the five soil samples per field was used for plating on semiselective NP-10 media to compare dilution plating with qPCR results.

Soil plating on semiselective media. In 2013, detection and quantification of $V$. dahliae in soil was carried out by plating and by qPCR. Only qPCR was used in 2014 because results from the plating test and qPCR correlated in 2013. Sorensen's NP-10 semiselective media was prepared as described by Kabir et al. (2004) with PGAsodium salt (P3850; Sigma), pH 5.5. Methionine (M-9500, $7.5 \mathrm{mg}$ in $1 \mathrm{ml}$ of water; Sigma) was added to each sample of $2.5 \mathrm{~g}$ of dry soil and incubated at $25^{\circ} \mathrm{C}$ for 1 week before air drying for 1 day. After drying, each sample was gently ground using a spoon and plated on five petri dishes with NP-10. The plates were incubated for 4 weeks in the dark at $25^{\circ} \mathrm{C}$. Following incubation, plates were gently washed under water to remove soil, and microsclerotial colonies of $V$. dahliae were counted under a microscope (Leica Type $300108, \times 8$ to $\times 100$ magnification). The number of viable $V$. dahliae units in the soil was expressed as CFU per gram of dry soil.

Seed health test. In 2013, detection and quantification of $V$. dahliae in spinach seed were carried out by the freeze-blotter test modified by du Toit et al. (2005), and by qPCR. Only qPCR was used in 2014 because results from the freeze-blotter test and qPCR correlated in 2013. In the freeze-blotter test, four independent measurements were done

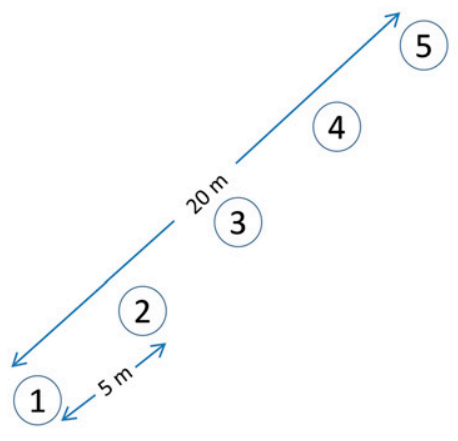

2013

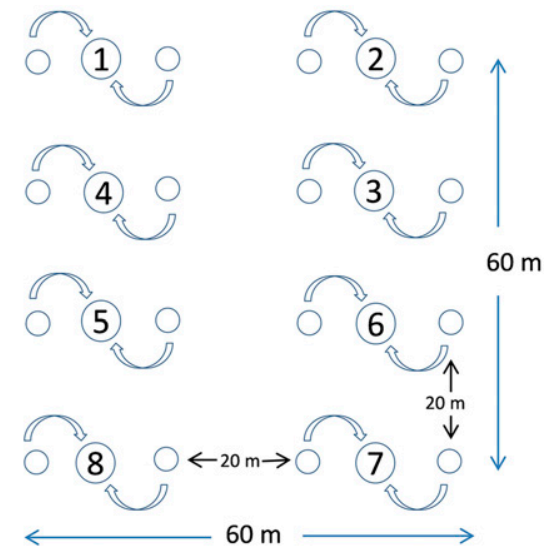

2014

Fig. 2. Soil sampling strategy used in the field in 2013 (left) and 2014 (right). In 2013, an infested area of the field was selected and five samples were collected in a diagonal line of $20 \mathrm{~m}$, having each sampling point $5 \mathrm{~m}$ apart. In 2014, an area of 1 ha in the field was selected and eight samples were taken $20 \mathrm{~m}$ apart, each consisting of two adjacent subsamples. 
for each sample. In all, 100 seeds were taken from each sample of harvested seed from commercial fields and 25 seeds were taken from the plants from each of the treatments in the semifield experiment. Germination paper (EDB number 742.085; Frisenette Aps) that had been moistened with $4 \mathrm{ml}$ of sterile double-distilled water in petri dishes $(9.6 \mathrm{~cm}$ in diameter) was used in the test. After placing seeds on the germination paper, plates were sealed with parafilm and incubated in a dark chamber at $22^{\circ} \mathrm{C}$ for $24 \mathrm{~h}$. Seed embryos were then killed by transferring seeds to $-20^{\circ} \mathrm{C}$ for $24 \mathrm{~h}$. In order to allow fungal growth, the seeds were transferred to a $22^{\circ} \mathrm{C}$ chamber having a cycle of $12 \mathrm{~h}$ of light and $12 \mathrm{~h}$ of darkness with black light (Narva LT 18W/073) and cool-white fluorescent light (Philips TL18W/79). One week after plating, the seed were examined by microscope (Leica Type $300108, \times 8$ to $\times 100$ magnification), and $V$. dahliae-infected seed were counted.

DNA extraction. Three different kits were used to extract DNA from fungal mycelium, soil, and seed. DNA from fungal mycelium was extracted using a DNeasy Plant mini kit (Qiagen). Fungal mycelium was placed in liquid nitrogen and ground in a Geno/Grinder 2000 (SPEX CertiPrep) with three 5-mm steel balls at 1,500 rpm three times at $30 \mathrm{~s}$ each. Ground samples were immediately mixed in lysis buffer and DNA was extracted according to the manufacturer's instructions, with a final elution in $100 \mu \mathrm{l}$ of elution buffer. This DNA from a culture of $V$. dahliae (CBS130341; CBS KNAW Fungal Biodiversity Centre) was used to produce a standard curve and as a positive control during qPCR.

Soil DNA extraction was performed using the PowerLyzer PowerSoil DNA Isolation Kit (Mo Bio Laboratories) according to the manufacturer's instructions. Samples were homogenized in a Geno/Grinder three times at $30 \mathrm{~s}$ each in $2-\mathrm{ml}$ tubes instead of the commercial homogenizer mentioned in the manual.

DNA from seed was extracted using a Sbeadex mini plant kit (LGC Genomics) on a King Fisher (KF24; Thermo Scientific). Each sample was mixed well before seed ( $7 \mathrm{~g}$ ) were frozen in liquid nitrogen and ground in a bead mill for $30 \mathrm{~s}$ using two steel beads. Lysate buffer $(100 \mu \mathrm{l})$ was added to $30 \mathrm{mg}$ of ground sample and incubated at $65^{\circ} \mathrm{C}$ for $10 \mathrm{~min}$. The samples were then centrifuged at $2,500 \times g$ for $10 \mathrm{~min}$, and $50 \mu \mathrm{l}$ of the resulting supernatant was used for DNA extraction and finally eluted in $50 \mu$ l of elution buffer PN. DNA was quantified using a NanoDrop ND 1000 spectrophotometer (Thermo Scientific).

qPCR. Detection and quantification of $V$. dahliae DNA in soil and seed was done using TaqMan qPCR. Amplification reactions were performed in a ViiA 7 Real-time PCR system (Life Technologies) using 384-well plates. Primers and probes (Vd-F29-947, Vd-R10761094 , and Vdhrc probe) for detection and quantification of $V$. dahliae were as described earlier (Bilodeau et al. 2012). A total reaction mixture of $15 \mu \mathrm{l}$ was used, containing $2 \mu \mathrm{l}$ of template, $1.35 \mu \mathrm{l}$ each of forward and reverse primers (10 $\mu \mathrm{M}$ stock), $0.75 \mu$ lof probe $(5 \mu \mathrm{M}$ stock), $2.05 \mu \mathrm{l}$ of water, and $7.5 \mu \mathrm{l}$ of Bio Probe Mix LoRox (PCR Biosystems). As negative and positive controls, $2 \mu \mathrm{l}$ of sterile water and a known $V$. dahliae DNA template (CBS 130341) were used. Thermal cycles in the qPCR consisted of an initial denaturation at $95^{\circ} \mathrm{C}$ for $10 \mathrm{~min}$ followed by 40 cycles of $95^{\circ} \mathrm{C}$ for $30 \mathrm{~s}$ and $60^{\circ} \mathrm{C}$ for $1 \mathrm{~min}$. Three technical replicates were prepared for each sample. Standards were included in each run using known dilutions of the $V$. dahliae-positive control. Standard curves were obtained using plots of critical threshold $(\mathrm{Ct})$ versus the logarithm of a 10-fold serial dilution $\left(1\right.$ to $\left.10^{-8}\right)$ of DNA.

Distribution of $\boldsymbol{V}$. dahliae inoculum. The distribution of $V$. dahliae in commercial fields and its influence on the health of harvested seed was evaluated using three separate soil samples per field. These three samples were $10 \mathrm{~m}$ apart in 2013 and more than $20 \mathrm{~m}$ apart (sampling points 1, 3, and 5; Fig. 1B) in 2014 and were analyzed to study the distribution of the pathogen in the field.

Data processing and statistical analysis. All statistical analyses were carried out in $\mathrm{R}$ (version 3.1.2) (R Core Development Team 2014). Ct values obtained from the qPCR assay were converted to amounts of DNA using the standard curve produced from dilutions of $V$. dahliae CBS130341 DNA that was included in each experiment. $\mathrm{Ct}$ values above 37.5 were inconsistent and, thus, were considered as negative. Because statistical assumptions were not fulfilled (homogeneity of variance and normality of residuals), $\log _{10}$ transformations of DNA amounts were carried out. The $\log _{10}$-transformed values for DNA amount detected in soil and harvested seed were subjected to linear regression analysis using the "lm" function in R. The amount of DNA in harvested seed was used as the response variable while DNA detected in soil was used as the explanatory variable. Box plots were used to visualize the distribution of the dataset. Significance tests were carried out using the analysis of variance test, and goodness of fit was tested using $R^{2}$ values. All statistical tests were considered significant if $P<0.05$.

\section{Results}

qPCR assay. A serial dilution of a DNA extract of $V$. dahliae (CBS130341) showed that $V$. dahliae DNA could be detected in a range from $12 \mathrm{ng}$ to $1.2 \mathrm{fg}$ and that the qPCR had an efficiency of $99.4 \%$ (data not shown). The $V$. dahliae dilution was used as a standard curve to calculate the amount of genomic DNA in unknown samples. Using samples from the 2013 semifield experiment, the amount of $V$. dahliae in soil was determined using qPCR as well as by dilution plating. Similarly, the qPCR and freeze-blotter tests were used to test for $V$. dahliae in seed samples. A significant correlation was observed between the qPCR and dilution plating for soil samples $\left(R^{2}=0.83, P=0.001\right)$ and the freeze-blotter method $\left(R^{2}=\right.$ $0.55, P=0.03$ ) for seed samples (Fig. 3).

Semifield experiments. In 2013 and 2014, spinach (6 plants/pot) was grown in semifield experiments in which pots with different levels of $V$. dahliae-infested soils were included. The amounts of $V$. dahliae in the soil dilutions were confirmed by qPCR (and by dilution plating in 2013). The soil inoculum levels in the dilutions were found to be different in the 2 years (Fig. 3). After plant maturation, spinach seed were harvested and the amount of $V$. dahliae DNA in the seed was determined by qPCR. In the seed harvested from the plants grown in soil dilutions below 1:6, no $V$. dahliae DNA could be detected in 2013 . In $2014, V$. dahliae was detected in all soil dilutions, except $0: 1$. This was in agreement with the fact that $V$. dahliae was detected in all harvested seed except in seed from the 0:1 soil dilution (Fig. 3).

Infested spinach fields in 2013. Soil and seed samples were taken from fields that, on the basis of symptom expression in spinach plants, were infested with $V$. dahliae. Results from dilution plating and $\mathrm{qPCR}$ to test for $V$. dahliae were compared. We found a significant correlation between $V$. dahliae CFU per gram of soil and the freeze-blotter test on harvested seed (percent seed infection; $R^{2}=$ $0.597, P=0.025$; Fig. 4 A). A weak correlation was also observed between the amount of DNA detected in the soil and the amount of DNA detected in harvested seed $\left(R^{2}=0.47, P=0.06\right.$; Fig. 4B).

Spinach fields in 2014. $V$. dahliae DNA was quantified in the soil samples that were collected in the spring before sowing using qPCR Similarly, levels of $V$. dahliae in the harvested seed were determined. Based on the qPCR results, the soils from 12 of 25 fields were found to be infested with $V$. dahliae. The amount of $V$. dahliae DNA in the harvested seed from soils with $V$. dahliae was significantly higher than in the seed from fields with no detectable $V$. dahliae DNA $(P=0.004$; Fig. 5). However, no correlation was observed between the amount of pathogen detected in the soil and in the seed (data not shown).

To trace the source of $V$. dahliae inoculum in the soils, the cropping history for the 25 selected fields was recorded 6 years back and these data were used to classify fields into three categories: (i) spinach grown at least once, (ii) $V$. dahliae hosts other than spinach included in the crop rotation, and (iii) no $V$. dahliae hosts included in the crop rotation during the last 6 years. Cropping history was useful to explain and trace back the source of inoculum in most of the soils (Table 1). Fields in which $V$. dahliae was detected had $V$. dahliaesusceptible host crops in the rotation within the last 6 years (10 of 12). Similarly, 6 of 7 fields with spinach in their crop history were infested with $V$. dahliae and, finally, only 2 of 10 soils with no history of $V$. dahliae were found to be infested.

Distribution of $\boldsymbol{V}$. dahliae in fields. In addition to the average amount of soil inoculum, the distribution of pathogen within the field was investigated in relation to seed infection. In 2013, we used the 
Soil
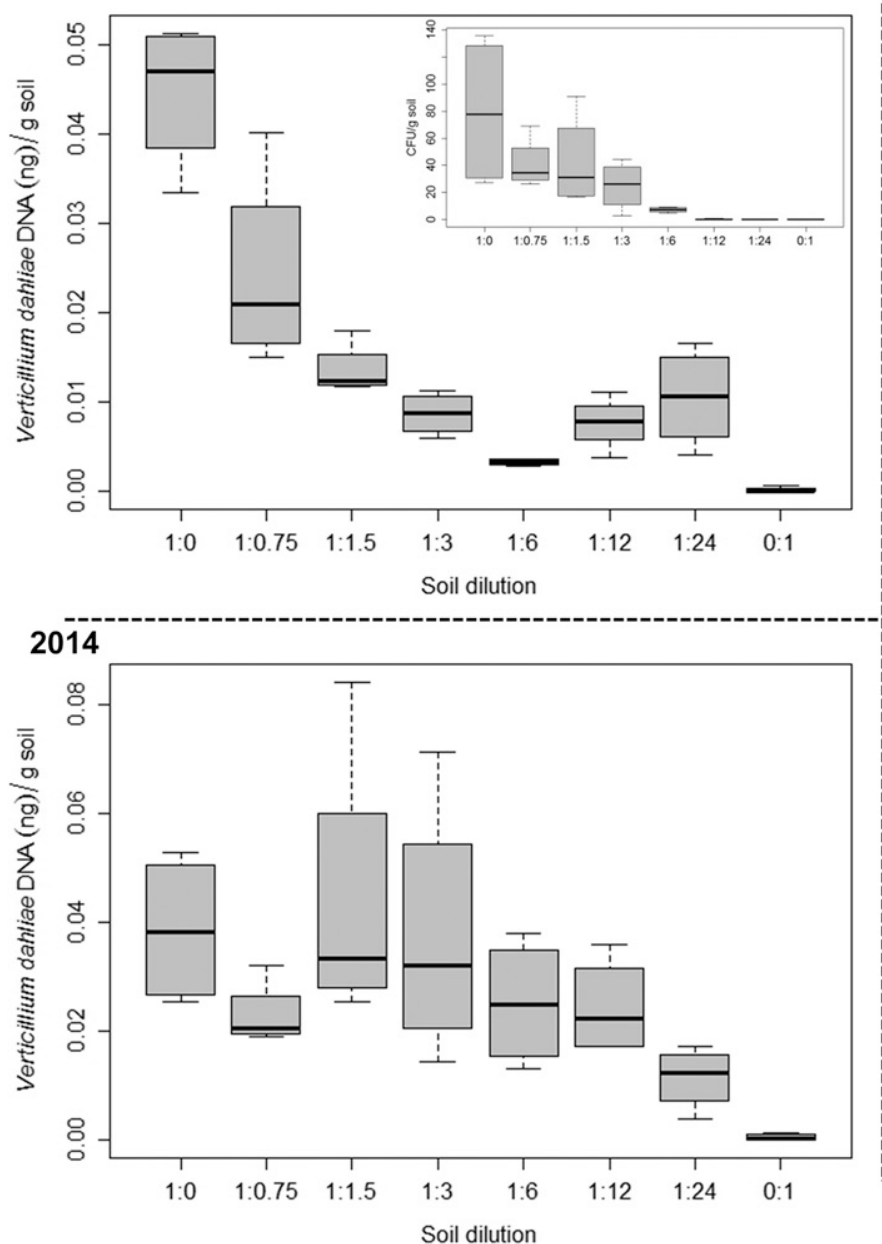

Seed
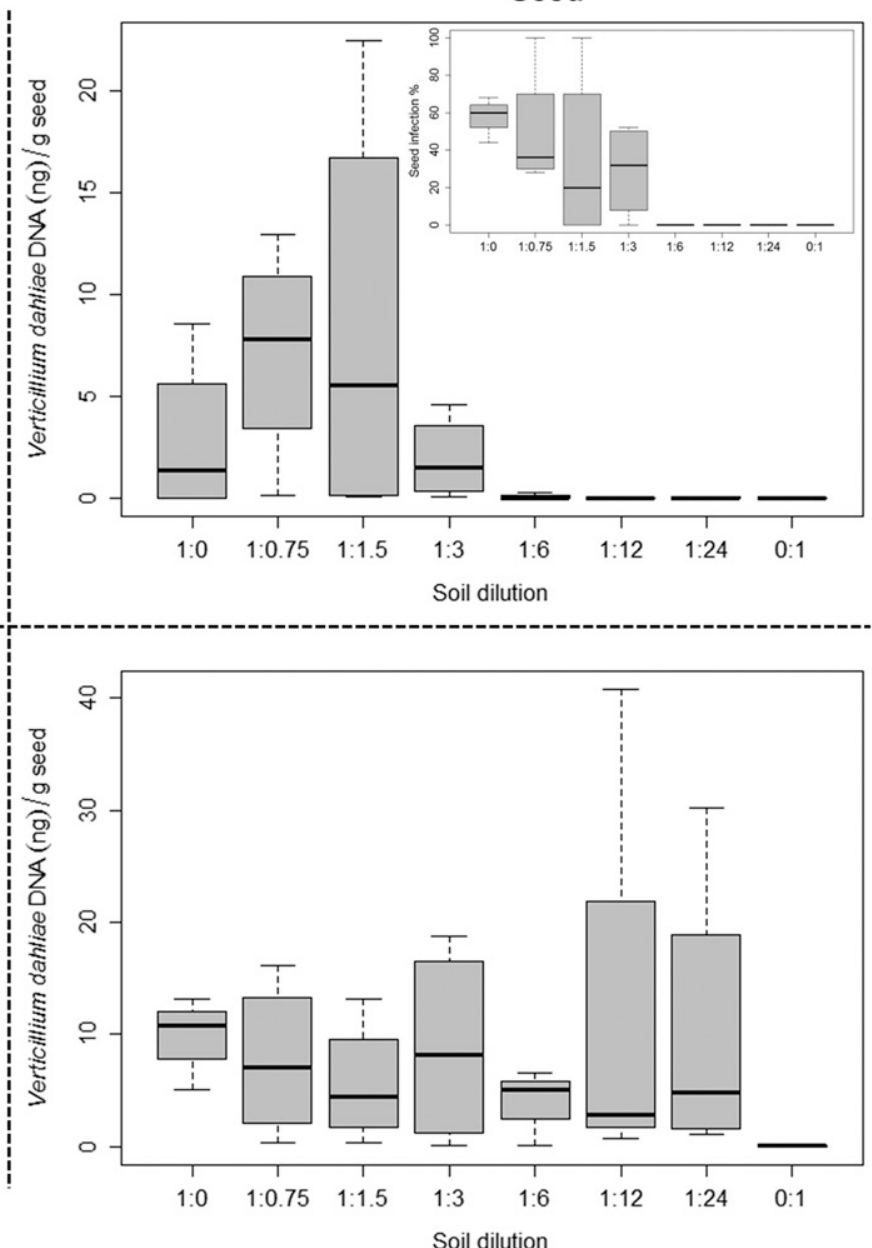

Fig. 3. Box plot diagram of the amount of Verticillium dahliae DNA detected in the semifield experiment. The amount of DNA detected in different soil dilutions is shown on the left and the harvested seed are shown on the right for the year 2013 (top) and 2014 (bottom). In 2013, insertions in the top left figures show (i) a comparison of quantitative polymerase chain reaction (qPCR) quantification with dilution plating in soil and (ii) a comparison of qPCR quantification with the freeze-blotter test in seed.

A

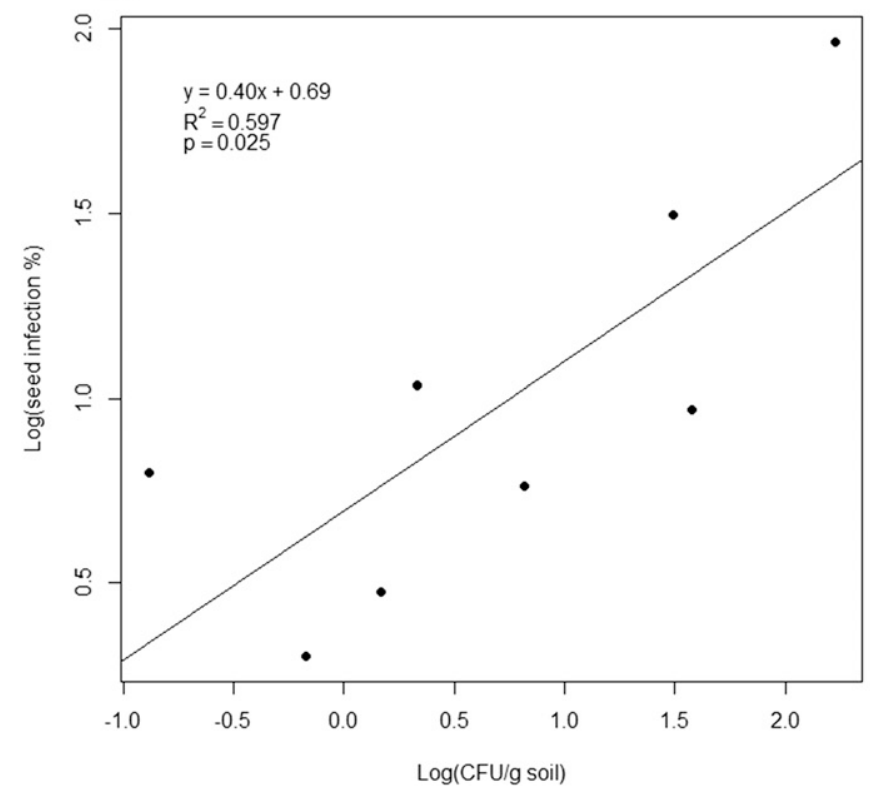

B

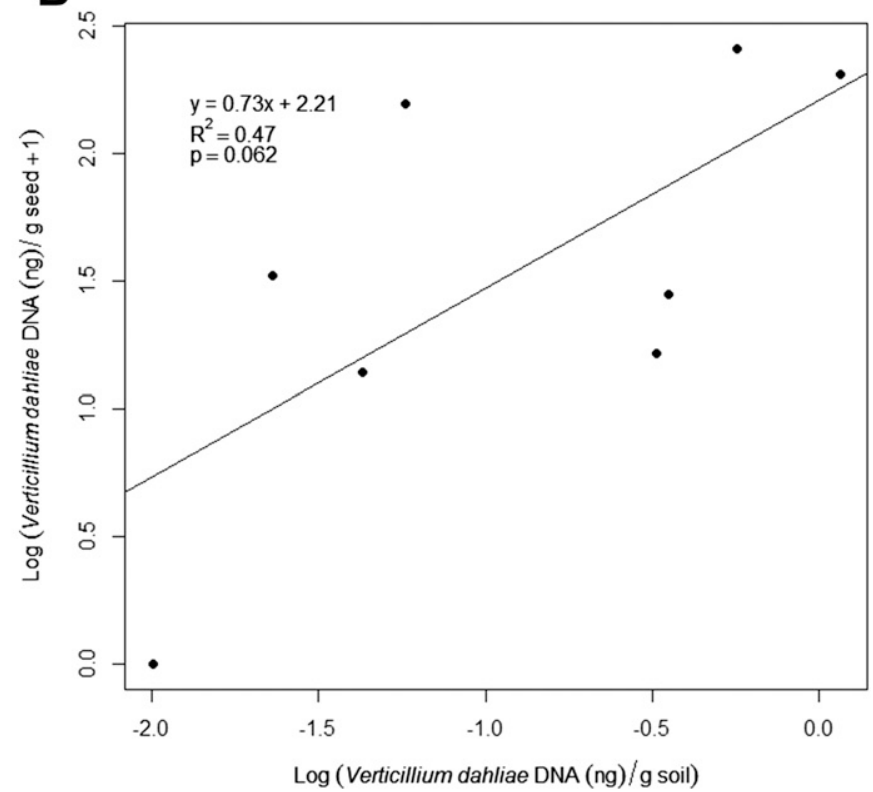

Fig. 4. Scatter plot of the amount of Verticillium dahliae detected in soil versus the amount detected in harvested seed in the 2013 fields. The amount of $V$. dahliae quantified using A, dilution plating (CFU per gram of soil) versus the seed infection percentage (freeze-blotter test) and B, quantitative polymerase chain reaction is shown. 
standard deviation of DNA amounts from three soil subsamples $10 \mathrm{~m}$ apart as a proxy for the distribution of the pathogen in the field. We observed that samples with high amounts of pathogen in the harvested seed generally had a lower standard deviation in the amount of pathogen detected in the soil among the three sampling points (data not shown). In order to understand the distribution of the pathogen in the field and its influence on $V$. dahliae levels in the harvested seed, we quantified $V$. dahliae DNA from three of the sampling points (numbers 1, 3, and 5; Fig. 2B) collected per field in 2014. The distribution of the pathogen could be classified as three positive samples, two positive samples, one positive sample, and no positive samples per field. The distribution of pathogen showed a patchy distribution within a distance of $20 \mathrm{~m}$; for instance, in field 17 (F17), which was highly infested in one sample and negative in the two other samples. It was observed that the fields in which all three sampling points were positive had the highest amount of pathogen in the seed (DNA at $159.3 \pm 121.9 \mathrm{ng} / \mathrm{g}$ of seed [mean \pm standard deviation]; Fig. 6). All the soils in which $V$. dahliae was detected in all three samples were also positive in the mixed sample (Table 2).

\section{Discussion}

It is of importance for the spinach seed industry to be able to determine soil inoculum levels in order to avoid establishing spinach seed production in soils with disease risks. However, the influence of $V$. dahliae soil infestation levels on the subsequent infection of harvested spinach seed is not fully understood. Therefore, the main objective of this study was to determine the effect of $V$. dahliae soil infestation on subsequent spinach infection. We quantified pathogen DNA in the soil and in the harvested seed from pots with controlled levels of $V$. dahliae inoculum and in commercial seed production plots. We showed that infection of $V$. dahliae in harvested seed

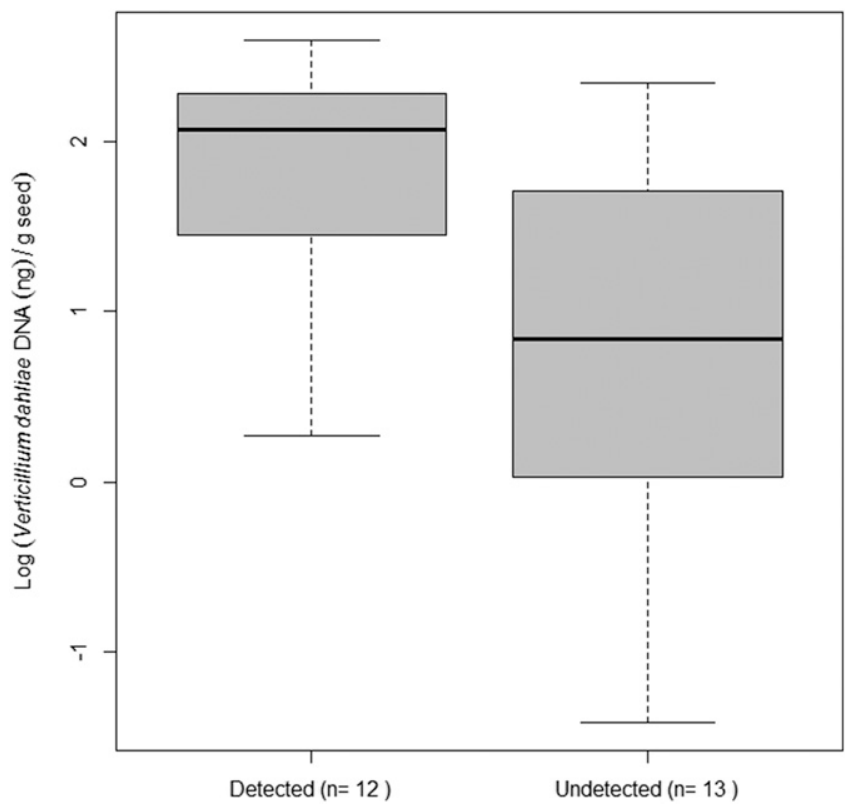

Fig. 5. Box plot diagram showing the amount of Verticillium dahliae DNA in harvested seed (log scale) from soil samples from spinach fields in 2014 that were tested positive ("Detected") or negative ("Undetected") for V. dahliae.

Table 1. Total number of fields with crop history record (6 years) and Verticillium dahliae detected using quantitative polymerase chain reaction in 2014

\begin{tabular}{lcc}
\hline & \multicolumn{2}{c}{ Number of fields } \\
\cline { 2 - 3 } Six year crop history & Total sampled & V. dahliae detected \\
\hline Spinach (at least once) & 7 & 6 \\
Other $V$. dahliae hosts (at least once) & 8 & 4 \\
No $V$. dahliae hosts & 10 & 2 \\
Total & 25 & 12 \\
\hline
\end{tabular}

strongly depends on the presence of pathogen inoculum in the soil. The results indicate a soil inoculum threshold level of $0.003 \mathrm{ng}$ of $V$. dahliae DNA for spinach seed infection. Crop rotation is an important aspect of spinach seed production and our results from 2014 show that, if a host has been grown in the field during the last 6 years, $V$. dahliae DNA could be detected in $80 \%$ of the fields.

The ability to extract DNA directly from soil opens the possibility of quantifying soilborne fungal pathogens using qPCR (Filion et al. 2003; Sanzani et al. 2014). qPCR assays are attractive for sensitive detection and quantification of pathogen inoculum in commercial seed production fields. Our results confirmed that an already developed TaqMan assay (Bilodeau et al. 2012) can be successfully used for quantification of $V$. dahliae DNA from soil and spinach seed.

In semifield experiments, there was a clear relationship between soil inoculum levels and the pathogen detected in the seed harvested from plants grown in the soil. With the exception of the 1:12 and 1:24 dilutions, high infection levels were observed in the seed from pots with $V$. dahliae DNA at more than $0.003 \mathrm{ng} / \mathrm{g}$ of soil (mean $\mathrm{Ct}$ value $=$ 34.2), whereas almost no seed infection was observed in soils with DNA at less than $0.003 \mathrm{ng} / \mathrm{g}$ of soil (dilutions below 1:3) in 2013. In the pots with $V$. dahliae quantities above this threshold, there was approximately the same level of seed infection, no matter what level of soil infestation (Fig. 3), suggesting that a certain amount of $V$. dahliae in the soil is required for the establishment of an infection in spinach. A low amount of $V$. dahliae DNA in seed was also observed in the soil with a $V$. dahliae quantity of DNA below $0.003 \mathrm{ng} / \mathrm{g}$ of soil in 2014 (0:1 soil dilution). The differences in the $V$. dahliae DNA quantities between the 2 years could be caused, for instance, by incomplete soil mixing or by growth of $V$. dahliae before samples were taken for DNA extraction. In similar experiments, a threshold of 4 to $7 \mathrm{CFU}$ of $V$. dahliae per gram of soil in cotton was determined for plant infection (Wei et al. 2015) and, in nursery trees, the threshold was at the detection limit using a qPCR assay (Goud et al. 2011).

In the field survey in 2013, in which soil samples were taken when spinach was grown in the field, there was only a weak relationship between the amount of $V$. dahliae detected in the soil and the amount of $V$. dahliae found in the harvested seed (Fig. 4). This confirmed the results from the semifield experiments, in which there was no obvious quantitative relationship between soil inoculum levels and seed infection levels above a threshold for $V$. dahliae DNA of approximately $0.003 \mathrm{ng} / \mathrm{g}$ of soil. However, soil inoculum density has previously been shown to be correlated with disease development in numerous crops such as potato, cotton, and strawberry (Harris and

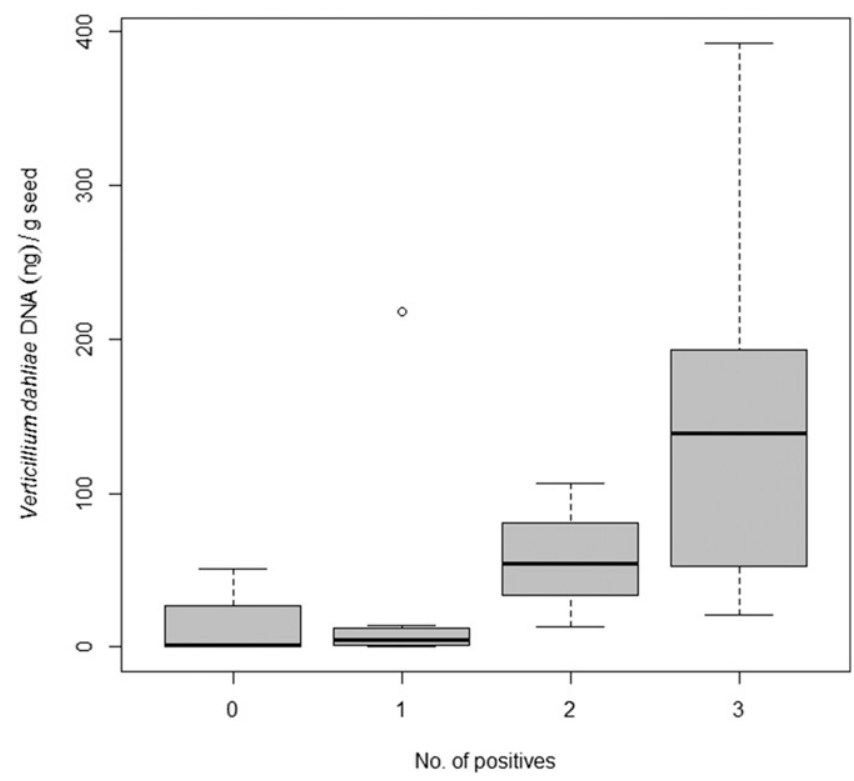

Fig. 6. Box plot showing the number of positive soil subsamples per field and the amount of pathogen detected in the seed (field experiment 2014). Three soil subsamples per field were subjected to quantitative polymerase chain reaction. 
Yang 1996; Nagtzaam et al. 1997; Wei et al. 2015). Also, in the field survey that was carried out in 2014, the amounts of pathogen in the harvested seed were not related to soil inoculum densities (data not shown), except that seed infection levels were higher in the seed from fields in which $V$. dahliae was detected (Fig. 5). These findings indicate that the presence of $V$. dahliae above a certain threshold can be used to predict disease development in the following spinach crop and, thus, can be used as a decision support tool (Gudmestad et al. 2007). The possibility of seed-to-seed transmission has been shown in earlier studies (du Toit et al. 2005) and the introduction of $V$. dahliae into new areas by infected spinach seed has been shown (Short et al. 2015). Although seed-to-seed infection could be important for the disease spread, its significance under field conditions is limited in numerous crops (Klosterman et al. 2009).

The weak correlation observed between soil infestation levels and infection levels in harvested seed in 2013 and 2014 could also be caused by host adaptation or specialization, which has previously been observed in $V$. dahliae populations in the field (Bhat and Subbarao 1999). Earlier reports have shown that inoculum threshold levels vary based on the aggressiveness of the fungal strains present in the soil (Bejarano-Alcázar et al. 1995). Several vegetative compatibility groups and differences in aggressiveness were found in $V$. dahliae from different crops (Iglesias-Garcia et al. 2013; Klosterman et al. 2009). The qPCR assay that was used in this study does not discriminate among these fungal pathogenicity groups. Studies on the relationship between inoculum densities of pathotypes and the associated disease have been reported in cotton (Bejarano-Alcázar et al. 1995) and olive (López-Escudero and Mercado-Blanco 2011). Further studies regarding $V$. dahliae pathotypes and host resistance could be useful for understanding the development of $V$. dahliae in spinach. Moreover, disease development is not solely dependent on the pathogen presence but, for instance, is also influenced by cultivar susceptibility (Mou et al. 2015; Villarroel-Zeballos et al. 2012)

Table 2. Comparison of the critical threshold $(\mathrm{Ct})$ values determined using quantitative polymerase chain reaction for detection of Verticillium dahliae from one combined soil sample (eight subsamples pooled), three soil subsamples (numbers 1, 3, and 5), and harvested seed from a field sampled in 2014

Soil

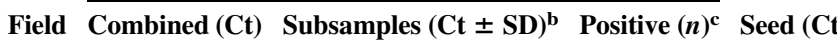

\begin{tabular}{lllll}
\hline F18 & UD & UD & 0 & 21.4 \\
F14 & UD & UD & 0 & 26.8 \\
F1 & UD & UD & 0 & 33.2 \\
F9 & UD & UD & 0 & 27.7 \\
F13 & UD & UD & 0 & 29.6 \\
F2 & UD & 36.3 & 1 & 19.0 \\
F17 & 32.8 & 30.3 & 1 & 23.5 \\
F8 & UD & 36.5 & 1 & 24.0 \\
F12 & UD & 36.5 & 1 & 24.6 \\
F6 & 35.6 & 33.4 & 1 & 26.8 \\
F7 & UD & 36.8 & 1 & 27.7 \\
F11 & UD & 36.6 & 1 & 27.7 \\
F15 & UD & $36.7 \pm 0.1$ & 2 & 20.2 \\
F22 & UD & $36.4 \pm 0.5$ & 2 & 21.3 \\
F4 & UD & $35.5 \pm 0.2$ & 2 & 23.6 \\
F24 & 31.5 & $30.8 \pm 1.1$ & 3 & 18.0 \\
F3 & 31.3 & $31.6 \pm 0.5$ & 3 & 18.3 \\
F10 & 31.1 & $30.7 \pm 0.2$ & 3 & 19.2 \\
F25 & 30.7 & $31.5 \pm 1.0$ & 3 & 19.3 \\
F16 & 35.9 & $35.5 \pm 1.4$ & 3 & 19.6 \\
F20 & 35.3 & $34.7 \pm 1.7$ & 3 & 19.8 \\
F5 & 33.8 & $35.3 \pm 1.1$ & 3 & 20.2 \\
F19 & 31.4 & $31.9 \pm 2.9$ & 3 & 21.3 \\
F21 & 32.8 & $31.8 \pm 0.3$ & 3 & 21.9 \\
F23 & 32.5 & $32.2 \pm 1.4$ & 3 & 22.8 \\
\hline
\end{tabular}

${ }^{\mathrm{a}} \mathrm{UD}=$ undetectable.

b Three soil subsamples; standard deviations (SD) are shown for samples detected in at least two soil subsamples.

${ }^{c}$ Number of positive samples detected. and environmental factors such as temperature, rainfall, soil type, and others (Klosterman et al. 2009).

The amount of pathogen detected in seed was highly influenced by the distribution of pathogen in the soil. We found that, when three subsamples from different areas in the field all were positive, this would usually result in a highly infected seed lot, too. Three positive samples in one field indicated an even distribution of the pathogen in the field whereas one positive of three samples indicated a patchy distribution of the pathogen. This is again reflected in a lower average seed infection level in the field with a patchy distribution (Fig. 6; Table 2).

In the field survey in 2014, the cropping history was recorded 6 years back. More than $80 \%$ of the soil samples in which $V$. dahliae was detected had at least one $V$. dahliae host crop during the last 6 years. Because of the long survival of resting structures and the wide host range of $V$. dahliae, soil inoculum levels are highly influenced by the crop history several years back (Davis et al. 1994; Klosterman et al. 2009; Xiao et al. 1998).

Soil sampling strategies are crucial for field studies considering the spatial distribution of the pathogen (Xiao et al. 1997). We used previously described soil sampling strategies for $V$. dahliae (Smith and Rowe 1984; Xiao et al. 1997). In addition to proper soil sampling, DNA extraction using a relatively high amount of soil or homogenizing high amounts of soil before taking the final sample for DNA extraction would be important to compensate for the patchy distribution of $V$. dahliae at the smaller scale as well as to increase the sensitivity of the assay, as shown in earlier studies (Bilodeau et al. 2012; OphelKeller et al. 2008; Woodhall et al. 2012,).

The qPCR assay used in this study was highly sensitive for detection of $V$. dahliae in spinach seed and was comparable with results obtained by plating. Some of the seed samples that were found to be negative using plating were found to be positive in the QPCR assay in our semifield experiment (data not shown). This is in agreement with findings by Feng et al. (2014), in which seed lots displayed lower pathogen incidence in the freeze-blotter test compared with qPCR assays in spinach. In this study, we implemented a qPCR assay developed earlier (Bilodeau et al. 2012). Different qPCR assays have recently been reported for quantification of $V$. dahliae using TaqMan (Bilodeau et al. 2012; Pasche et al. 2013) or SYBR green chemistry (Atallah et al. 2007; Duressa et al. 2012; Gayoso et al. 2007; Wei et al. 2015). A comparative study of several qPCR assays was carried out by Gramaje et al. (2013) and two assays, one SYBR green assay (Atallah et al. 2007) and the TaqMan assay (Bilodeau et al. 2012), used herein were reported to be the most robust and well suited for quantification of $V$. dahliae.

This is the first attempt to study the effect of $V$. dahliae soil inoculum levels on the amount of pathogen in harvested seed by quantifying $V$. dahliae DNA. We found that soil inoculum over a certain level strongly influenced pathogen levels detected in the harvested seed in both a semifield setup and open fields. Furthermore, our study indicated that the spatial distribution of the pathogen in the field was important in determining pathogen levels in the seed. Knowledge of $V$. dahliae soil inoculum levels in fields intended for spinach seed production could be useful for the seed industry and seed growers to make decisions on crop rotations and other management options.

\section{Acknowledgments}

We thank the seed companies Syngenta, Jensen Seed A/S, and Vikima Seeds A/S for providing spinach seed and soil samples. Funding of this study was provided by the Ministry of Food Agriculture and Fisheries: Product development-Vegetable seed for baby leaf production (J. nr. 3412-08-02345), GUDP (J. nr: 34009-120528), Frøafgiftsfonden, and Aarhus University.

\section{Literature Cited}

Atallah, Z. K., Bae, J., Jansky, S. H., Rouse, D. I., and Stevenson, W. R. 2007 Multiplex real-time quantitative PCR to detect and quantify Verticillium dahliae colonization in potato lines that differ in response to Verticillium wilt. Phytopathology 97:865-872.

Bejarano-Alcázar, J., Melero Vara, J. M., Blanco-Lopez, M. A., and Jimenez Diaz, R. M. 1995. Influence of inoculum density of defoliating and nondefoliating pathotypes of Verticillium dahliae on epidemics of Verticillium wilt of cotton in southern Spain. Phytopathology 85:14774-14781. 
Bhat, R. G., and Subbarao, K. V. 1999. Host range specificity in Verticillium dahliae. Phytopathology 89:1218-1225.

Bilodeau, G. J., Koike, S. T., Uribe, P., and Martin, F. N. 2012. Development of an assay for rapid detection and quantification of Verticillium dahliae in soil. Phytopathology 102:331-343.

Daayf, F. 2014. Verticillium wilts in crop plants: Pathogen invasion and host defence responses. Can. J. Plant Pathol. 37:8-20.

Davis, J. R., Pavek, J., Corsini, D. L., Sorensen, L. H., Schneider, A. T., Everson, D. O., Westermann, D. T., and Huisman, O. C. 1994. Influence of continuous cropping of several potato clones on the epidemiology of Verticillium wilt of potato. Phytopathology 84:207-214.

Deleuran, L. C. 2011. Innovation in vegetable seed production and the role of consumers in the organic and conventional babyleaf chains: The case of Denmark. Renew. Agric. Food Syst. 26:149-160.

Duressa, D., Rauscher, G., Koike, S. T., Mou, B., Hayes, R. J., Maruthachalam, K., Subbarao, K. V., and Klosterman, S. J. 2012. A real-time PCR assay for detection and quantification of Verticillium dahliae in spinach seed. Phytopathology 102:443-451.

du Toit, L. J., Derie, M. L., and Hernandez-Perez, P. 2005. Verticillium wilt in spinach seed production. Plant Dis. 89:4-11.

du Toit, L. J., and Hernandez-Perez, P. 2005. Efficacy of hot water and chlorine for eradication of Cladosporium variabile, Stemphylium botryosum, and Verticillium dahliae from spinach seed. Plant Dis. 89: 1305-1312.

Feng, C., Mansouri, S., Bluhm, B. H., du Toit, L. J., and Correll, J. C. 2014. Multiplex real-time PCR assays for detection of four seedborne spinach pathogens. J. Appl. Microbiol. 117:472-484.

Filion, M., St-Arnaud, M., and Jabaji-Hare, S. H. 2003. Direct quantification of fungal DNA from soil substrate using real-time PCR. J. Microbiol. Methods 53:67-76.

Fradin, E. F., and Thomma, B. P. 2006. Physiology and molecular aspects of Verticillium wilt diseases caused by $V$. dahliae and V. albo-atrum. Mol. Plant Pathol. 7:71-86.

Gayoso, C., De Ilárduya, O. M., Pomar, F., and Merino De Cáceres, F. 2007. Assessment of real-time PCR as a method for determining the presence of Verticillium dahliae in different Solanaceae cultivars. Eur. J. Plant Pathol. 118:199-209.

Goud, J. K. C., Termorshuizen, A. J., and van Bruggen, A. H. C. 2011. Verticillium wilt in nursery trees: Damage thresholds, spatial and temporal aspects. Eur. J. Plant Pathol. 131:451-465.

Gramaje, D., Pérez-Serrano, V., Montes-Borrego, M., Navas-Cortés, J. A, Jiménez-Díaz, R. M., and Landa, B. B. 2013. A comparison of real-time PCR protocols for the quantitative monitoring of asymptomatic olive infections by Verticillium dahliae pathotypes. Phytopathology 103:1058-1068.

Gudmestad, N. C., Taylor, R. J., and Pasche, J. S. 2007. Management of soilborne diseases of potato. Australas. Plant Pathol. 36:109-115.

Harris, D. C., and Yang, J. R. 1996. The relationship between the amount of Verticillium dahliae in soil and the incidence of strawberry wilt as a basis for disease risk prediction. Plant Pathol. 45:106-114.

Iglesias-Garcia, A. M., Villarroel-Zeballos, M. I., Feng, C., du Toit, L. J., and Correll, J. C. 2013. Pathogenicity, virulence, and vegetative compatibility grouping of Verticillium isolates from spinach seed. Plant Dis. 97: 1457-1469.

Inderbitzin, P., and Subbarao, K. V. 2014. Verticillium systematics and evolution: How confusion impedes Verticillium wilt management and how to resolve it. Phytopathology 104:564-574.

ISTA. 2011. International Rules for Seed Testing, Chapter 5. International Seed Testing Association,Bassersdorf, Switzerland.

Kabir, Z., Bhat, R. G., and Subbarao, K. V. 2004. Comparison of media for recovery of Verticillium dahliae from soil. Plant Dis. 88:49-55.

Klosterman, S. J., Atallah, Z. K., Vallad, G. E., and Subbarao, K. V. 2009. Diversity, pathogenicity, and management of Verticillium species. Annu. Rev. Phytopathol. 47:39-62.
López-Escudero, F. J., and Mercado-Blanco, J. 2011. Verticillium wilt of olive: A case study to implement an integrated strategy to control a soil-borne pathogen. Plant Soil 344:1-50.

Luo, X., Xie, C., Dong, J., Yang, X., and Sui, A. 2014. Interactions between Verticillium dahliae and its host: Vegetative growth, pathogenicity, plan immunity. Appl. Microbiol. Biotechnol. 98:6921-6932.

Mou, B., Klosterman, S. J., Anchieta, A., and Wood, E. 2015. Characterization of spinach germplasm for resistance against two races of Verticillium dahliae. HortScience 50:1631-1635.

Nagtzaam, M. P. M., Termorshuizen, A. J., and Bollen, G. J. 1997. The relationship between soil inoculum density and plant infection as a basis for a quantitative bioassay of Verticillium dahliae. Eur. J. Plant Pathol. 103:597-605

Nicot, P. C., and Rouse, D. I. 1987. Relationship between soil inoculum density of Verticillium dahliae and systemic colonization of potato stems in commercial fields over time. Phytopathology 77:1346-1355.

Olesen, M. H., Deleuran, L. C., Gislum, R., and Boelt, B. 2014. Preventing an increase in Verticillium wilt incidence in spinach seed production. Crop Prot. 66:107-113.

Ophel-Keller, K., McKay, A., Hartley, D., Herdina, and Curran, J. 2008. Development of a routine DNA-based testing service for soilborne diseases in Australia. Australas. Plant Pathol. 37:243-253.

Pasche, J. S., Mallik, I., Anderson, N. R., and Gudmestad, N. C. 2013. Development and Validation of a real-time PCR assay for the quantification of Verticillium dahliae in potato. Plant Dis. 97:608-618.

R Core Development Team. 2014. R: A Language and Environment for Statistical Computing. Online publication. R Foundation for Statistical Computing, Vienna. http://www.R-project.org/

Sanzani, S. M., Li Destri Nicosia, M. G., Faedda, R., Cacciola, S. O., and Schena, L. 2014. Use of Quantitative PCR detection methods to study biocontrol agents and phytopathogenic fungi and oomycetes in environmental samples. J. Phytopathol. 162:1-13.

Schena, L., Nigro, F., Ippolito, A., and Gallitelli, D. 2004. Real-time quantitative PCR: A new technology to detect and study phytopathogenic and antagonistic fungi. Eur. J. Plant Pathol. 110:893-908.

Short, D. P. G., Gurung, S., Koike, S. T., Klosterman, S. J., and Subbarao, K. V 2015. Frequency of Verticillium species in commercial spinach fields and transmission of $V$. dahliae from spinach to subsequent lettuce crops. Phytopathology 105:80-90.

Smith, V. L., and Rowe, R. C. 1984. Characteristics and distribution of propagules of Verticillium dahliae in Ohio potato field soils and assessment of two assay methods. Phytopathology 74:553-556.

Villarroel-Zeballos, M. I., Feng, C., Iglesias, A., du Toit, L. J., and Correll, J. C 2012. Screening for resistance to Verticillium wilt in spinach and isolation of Verticillium dahliae from seed of spinach accessions. HortScience 47: 1297-1303.

Wei, F., Fan, R., Dong, H., Shang, W., Xu, X., Zhu, H., Yang, J., and Hu, X. 2015 Threshold microsclerotial inoculum for cotton Verticillium wilt determined through wet-sieving and real-time quantitative PCR. Phytopathology 105: 220-229.

Wilhelm, S. 1955. Longevity of the Verticillium wilt fungus in the laboratory and field. Phytopathology 45:180-181.

Woodhall, J. W., Webb, K. M., Giltrap, P. M., Adams, I. P., Peters, J. C., Budge, G. E., and Boonham, N. 2012. A new large scale soil DNA extraction procedure and real-time PCR assay for the detection of Sclerotium cepivorum in soil. Eur. J. Plant Pathol. 134:467-473.

Xiao, C. L., Hao, J. J., and Subbarao, K. V. 1997. Spatial patterns of microsclerotia of Verticillium dahliae in soil and Verticillium wilt of cauliflower. Phytopathology 87:325-331.

Xiao, C. L., Subbarao, K. V., Schulbach, K. F., and Koike, S. T. 1998. Effects of crop rotation and irrigation on Verticillium dahliae microsclerotia in soil and wilt in cauliflower. Phytopathology 88:1046-1055. 